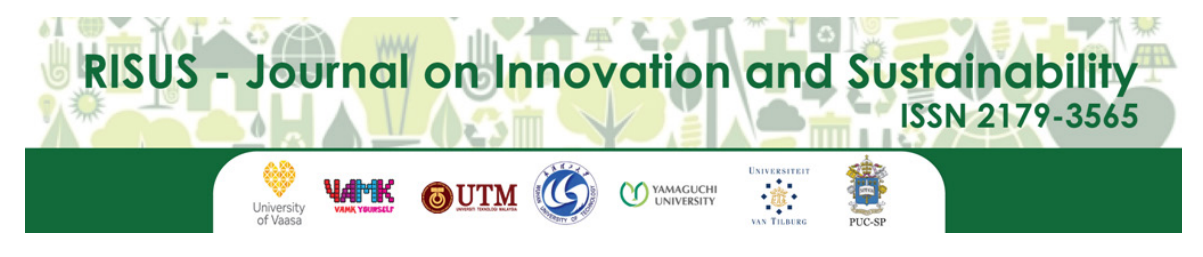

RISUS - Journal on Innovation and Sustainability volume 9, número 1 - 2018

ISSN: $2179-3565$

Editor Científico: Arnoldo José de Hoyos Guevara Editora Assistente: Lívia Lopes Aguiar

Avaliação: Melhores práticas editoriais da ANPAD

\title{
LEAN SIX SIGMA: MULTIPLE CASE STUDY
}

\author{
Lean Six Sigma: Estudo de Caso Múltiplo
}

\begin{abstract}
Orlando Roque da Silva ${ }^{1}$, Alessandro Marco Rosini ${ }^{1}$, Arnoldo J H Guevara ${ }^{2}$, Angelo Palmisano ${ }^{1}$, Delvio Venanzi ${ }^{1}$

1 University Center of Faculdades Metropolitanas Unidas FMU, São Paulo, Brazil

2 Pontificial University Catholic of São Paulo, São Paulo, Brazil

E-mail: orlandoroque@uol.com.br, alessandro.rossini@yahoo.com, arnoldodehoyos@yahoo.com.br, angelopalmisano@uol.com.br,delvio.venanzi@prof.uniso.br
\end{abstract}

\begin{abstract}
Lean Six Sigma is a management focused on quality and productive performance in operating systems. This article discusses the foundations of this methodology through of two different conceptions of management, Lean Manufacturing and Six Sigma. First of the article explain the DMAIC (define measure, analyze, improve and control) and their respective phases, after the Lean philosophy with the sipoc and value stream mapping techniques. The article aims to show integration of these two conception and their results. The methodology consisted in a theory was based on a literature search an exploratory research which consisted of three case studies in differences companies located in Sorocaba, São Paulo. In this article studies the applying of Lean Six Sigma and its results.
\end{abstract}

Key words: Lean Six Sigma; Quality; Production management

Resumo: Lean Six Sigma é um gerenciamento focado em qualidade e desempenho produtivo de sistemas operacionais. Este artigo discute os fundamentos desta metodologia através de duas concepções diferentes de gestão, Lean Manufacturing e Six Sigma. A primeira parte do artigo explica o DMAIC (definir medida, analisar, melhorar e controlar) e suas respectivas fases, após a filosofia Lean com as técnicas de mapeamento SIPOC e Fluxo de Valor. O artigo pretende mostrar a integração dessas duas concepções e seus resultados. A metodologia consistiu em uma teoria baseada na pesquisa bibliográfica e uma pesquisa exploratória que consistiu em três estudos de caso em empresas diferenciadas localizadas em Sorocaba, São Paulo. Neste artigo estuda a aplicação do Lean Six Sigma e seus resultados. Palavras Chave: Lean Six Sigma; Qualidade; Gestão de Produção. 


\section{INTRODUCTION}

The competitiveness in the XXI century has required of the companies greater efforts in quality, productivity and cost reduction. To achieve these goal industries searches new methods of production management. In reason of be competitive the companies have been improving areas related to quality improving their processes and operations. To Habidin and Yusof, the best strategy for attain those purposes is through the quality management, such as quality program initiatives and process improvement (Habidin, Yusof, 2012). There are several methodologies to been used, but one stands out for a functionality, complementarity, and effectiveness: the Lean Six Sigma (Antony, Kumar, 2012).

Six Sigma and Lean Manufacturing is a combination of two mighty management that evolved in a joint manner in broad and together, as a result, bring possibilities to do powerful efforts in the areas that offer potential improvement into comprehensive management systems, Mousa $^{1}$, Antony and Kumar. It is a methodology increase efficiency of the process, speed while and accuracy with a statistics tolls basing in a strong project of a clear target setting (Stan, Mărăscu, 2012; Aghili, 2011; Okhovat, 2012).

Lean and Six Sigma settle process inefficiency (Lean - speed and efficiency) and process variation (Six Sigma - precision and accuracy) as a single effort (Bhargava, 2010). "Lean focuses on eliminating non-value-adding steps and activities in a process, and Six Sigma focuses on reducing variation from the remaining value-adding steps, which provides us with a powerful tool for breakthrough improvement". Six Sigma so as Lean evolved an integrated manner, or even of different focuses align the same goal and therefore can supplant one another.

The performance of organizations to Stan and Mărăscu depends on careful analysis of sustainable processes, products and services to reduce manufacturing costs and provide quality. A considerable advancement Lean Six Sigma not only in the quality of processes, but also in suppression costs and ensuring the customer satisfaction at a competitive price, it is "the greatest opportunity for improvement in cost, quality ${ }^{2}$ and lead time" Dumitrescu et al.

The purpose is to research the perspective of quality in productive operations and observe the results achieved through the implementation of Lean Six Sigma methodology in two company $\mathrm{X}$ and $\mathrm{Y}$ in three distinct problems with different approaches.

\section{Theoretical Framework - Lean Six Sigma}

\section{Six Sigma}

The Six Sigma developed by Motorola in 1980 as a strategy to increase profits and improve the effectiveness and efficiency of operations (Hoon, Anbari, 2006). According to Jiménez and Amaya, this methodology aims to increase the ability of the processes.

\footnotetext{
${ }^{1}$ Mousa, A., Lean, Six sigma and Lean six sigma overview. International Journal of Scientific \&Engineering Research, vol. 4, issue 5, May-2013 1137 ISSN 2229-5518 IJSER (C) 2013. Available in: <http://www.ijser.org>.

${ }^{2}$ Dumitrescu C., Dumitrache M. The Impact of Lean Six Sigma on the Overall Results of Companies. Available in: $<$ html do arquivo http://www.management.ase.ro/reveconomia/2011-2/26.pdf $>$. Access in: 08 ago. 2014
} 
The Six Sigma brings important advance to the operating system as it directs the entire organization to the same end: meet customer requirements, align processes and excel analytical rigor and running second (Bhargava et al, 2010). Its fundamental principle for Celis and Garcaí is the client and the objective of achieving better results in a continuous improvement cycle(Celis, Garcaí, 2012). Therefore, its definition ranges from errors processes to customer satisfaction processes and outcomes and their focus is to improve operations.

The methodology act through of DMAIC (Define, Measure, Analyze, Improve and Control), figure 1. This method divides the process of improvement in some phases that favors the recognition errors and their causes to eliminating them.

The DMAIC dispose of support tools of toolboxes. Commonly are used sipoc, boxplot, capability studies, statistical process control, measurement system analysis, cause and effect diagram, cause and effect analysis, data collection, hypothesis testing, regression, and brainstorming.In DMAIC phases is import to use these tools to analyze and achieve better results.

Its phases are described below in Figure 1, DMAIC phases, and include in its description of its steps the sequence and the tolls:

Table 1 Phases of DMAIC

\begin{tabular}{|c|c|}
\hline Phase & Description \\
\hline Define & $\begin{array}{l}\text { In this phase we clarify the process or product that needs improvement. Define the most } \\
\text { suitable team members to work with the improvement. Define the customers of the process } \\
\text { which are the internal or external customers, their needs and requirements, and create a map of } \\
\text { the process that should be improved. }\end{array}$ \\
\hline Measure & $\begin{array}{l}\text { Identify the key factors that have the most influence on the process, and decide upon how to } \\
\text { measure them and in this phase we can collect fresh data to clarify the sources of process } \\
\text { variation }\end{array}$ \\
\hline Analyze & Analyse the factors that need improvements and we can reduce the factors of process variation. \\
\hline Improve & $\begin{array}{l}\text { Design and implement the most effective solution. Cost-benefit analyses should be used to } \\
\text { identify the best solution and hypothesis test to assure the improvement. }\end{array}$ \\
\hline Control & $\begin{array}{l}\text { Verify if the implementation was successful and ensure that the improvement sustains over } \\
\text { time. So we can use control tools such as control plan. }\end{array}$ \\
\hline
\end{tabular}


The DMAIC manages and leads projects supported by leaders and by actions previously defined and supported in the statistical relationships and controls that generate safe and visible results for system improvement.

\section{Lean manufacturing}

Lean manufacturing comes from the Toyota production system in the 80 . According to Chen,this methodology consists of two central points: remove activities that do not add value and add value in production as much as possible (Chen, 2008). The focus is to eliminate "anything other than the minimum amount of equipment, materials, parts, space and time which are absolutely essential to add value to the product". Lean emphasizes waste reduction to reduce costs. So the importance is support productivity sequence, quality and product development dynamics and effectively withoutremains.

This methodology encompasses all aspects of industrial operations as integrated system: product-manufacturing, organization, resources, services and supply chains, for this reason can reduces variability of suppliers and process in the industry. The Lean improves the flow of the holistic management process, and thus, removes waste and unnecessary activities.

The purpose of Lean is to create skillful proceedings, which have value at the end of the chain, so the main goal concentrated in the waste reduction and the creation of value as defending Celis and Garcaí. The process also has customer focus and satisfaction. Therefore, this approach has its relevance in go down costs and increase profits by concentrating the various activities and processes into a single philosophy avoiding the inefficiency of operations and rework.

The Lean philosophy have successful initiatives, since the value chain flowing connection provides agile management, able to adapt quickly to any changes in industry Subramanian ${ }^{1}$ (Todorut et. al., 2012). For accomplish advances in philosophy, there are techniques such as value stream map, the VSM and supplier - input - process - output - consumers, theSIPOC. Using to track down flaws in the process provides a reliable in analysis of the value chain.

According to Bramu(Bramu, 2014) "The application of SIPOC and VSMidentifying the waste of different kinds and evolving action plan for elimination of such wasteful. Delineate the process in detail, and find out whether the steps add value or not". In the first step in a lean transition is to identify and analyze the value-added processes business and do not add value. If an action does not add value, it should be modified or eliminated from the process. The Value Stream Mapping (VSM)(Basu, 2009) provides a reliable qualitative analysis tool for. The benefits of VSM and SIPOC are many, including the provision of a common language when considering manufacturing processes, a dynamic and quick view and developing the idea of the mapping process itself becoming a continuous tool.

\footnotetext{
${ }^{1}$ Subramanian. Integrating Lean Six Sigma, Projects to your strategy - How to integrate LSS - People, Systems, Methods, Roadmaps, Tools \& Techniques. Available in: $<$ http://www.slideshare.net/anandsubramaniam/lean-six -sigma-projectsstrategy-linkage> . Access in: 05 ago. 2014
} 
Moreover, considering the advancement of processes and adaptation to changes as the main concept for organization, therefore, Lean manufacturing integrates sectors and their activities in a single segment management. Through the VSM and SIPOC can realize eradication activities, suppresses costs, allows adjustments in processes and operations and bring customer value generating profitability and making the company competitive.

\section{Lean Six Sigma}

Lean Six Sigma is the latest generation of business improvement methodology. It is based on two previous philosophies (Lean Manufacturing and Six Sigma) and adopts effective aspects of these respective approaches, according to Mousa. This technique "uses tools from both toolboxes, in order to get the better of the two methodologies, increasing speed while also increasing accuracy" Palamisamy. The Lean Six Sigma have several benefits, highlights some of them in figure below:

Table 2 Lean Six Sigma Benefits

Lean Six Sigma Benefits
Ensuring services/products conform to what the customer needs ("voice of the customer")
Removing non-value adding steps (waste) in critical business processes.
Reducing cost of poor quality.
Reducing cost of poor quality.
Reducing cost of poor quality. Delivering the correct product/service at the right time in the right place."

Source: Antony (2005)

Lean Manufaturing and Six Sigma are aligned for the purpose of satisfy the customer and improve processes, but each serves different areas of quality, while the first concerns itself with removing activities that do not add value, another strives to maximize the productive performance. According to Anthony and Kumar, the scope of Lean is to create a setting to improve the flow and eliminating waste, - approaching ensure smooth and uninterrupted product flow through the organization to produce only what is required by the customer\|(Chakravorty, 2009). The Six Sigma scopes is to identify and quantify the problems related to process variation,Anthony and Kumar, "focuses on" "critical to quality" processes or operations.Six Sigma relies on the selection of appropriate projects which are strategically relevant to both the organization and the customerl, Chakravorty.

The advantage of the integration is "the beneficial combination in providing focus on flow, value streams and waste reduction, as well as focus on variation reduction through structured problem solving and application of statistical tools and techniques"1.

Also Chen and Todorut et al. emphasize Lean Six Sigma as synergistic management, because, using the methods simultaneously offers capacity to handle all kinds of problems of processes and operations. The connection process, able to solve the problems operational level until strategy, originates products and services in high-level within a competitive price, also achieved an excellent performance and eliminates wastes.

\footnotetext{
${ }^{1}$ Jenica A. P., Mihai G., SORIN A., Using Lean Six Sigma as a motivation tool for process improvement. Academy of Economic Studies Bucharest Business Administration. Available in: <http://anale.steconomiceuoradea.ro/volume /2010/ n2/067.pdf $>$. Access in: 10 ago. 2014
} 
For these reasons, the development of management leads to superior financial performance encompasses new requirements, brings differentiation of products and services and sets new processes.

The Lean philosophy reinforces the structure and provides strategic direction for improvement. Guides the overall dynamics of the system and reports the current state of operations. The Six Sigma project identifies and focuses on improvement. Leads the system to the desired future state. This description can be seen in Table 3.

Table 3 Lean Six Sigma Interconnections

\begin{tabular}{cc}
\hline Lean Manufacturing & Six Sigma \\
\hline $\begin{array}{c}\text { Wide - comprises the whole, improves capacity, } \\
\text { focuses on continuity and value chain - single process of } \\
\text { improvement of flows. }\end{array}$ & $\begin{array}{c}\text { Complex and focused - understands the details, } \\
\text { appreciate and improve the situation by the tools - } \\
\text { focuses on control capability to meet customer }\end{array}$ \\
\hline
\end{tabular}

Source:adapted Jenica et al. (2014).

The Lean Six Sigma ensures the organization achieve the proposals established and brings so not only with gains in profitability, but customer loyalty and continuity of increasingly effective processes.

\section{METHODOLOGY}

The search strategy taken was the case study. The choice of this approach is in accordance with the Yin propositions (Yin, 1994), because it aims - to investigate a current phenomenon inside of its real context, when the distinctions between phenomenon and context are not clearly defined and using many sources of evidencell. The Field research, conducted through case studies, used a qualitative method of descriptive study (or explorative), adopting the matching strategy between pairs of cases. Yin, the qualitative methods are characterized by a strong focus on comprehension of facts instead of its measurement. It was considered a pair of studies for each mentioned patterns.

It was sent a semi-structured questionnaire to the managers. The interviews were recorded, after feedback from the managers and evaluated with the researcher and transcribed to a magnetic device with participatory observation, where the main issues and points addressed to structure the work are attached to this article. The document examination was also the subject of the study. In each case study, a member of strategic level (directors) and tactical (managers) was interviewed, aiming an analysis of the answers of the questions to a better understanding of the vision of each interviewee. It is worth mentioning that these interviewees have at least 10 years of experience in companies.

\section{CASE STUDIES}

The case studies surveyed case number 1,2 and 3, refer to diverse industries of Sorocaba, city state São Paulo. The purpose of the studies is to check the application of Lean Six Sigma in different settings demonstrating its results in resolution of problems involving the variability of manufacturing processes. 4.1 Case number 1 The case number 1 it is about a low profitability in production system caused by inefficiency machine. The manufacturing process has four different operations tomanufacture a component. One of operations stations has a high time of set up and it is unsatisfactory compared to other machines of the same function. The consequence of this is stopping the ideal flow from operations in the process (leadtime). The relevance of the project is centered on two factors: cost and time factors that have a direct impact on profits of industry. 
The cost of the process, in low profitability situation, was estimated at around R\$ $2,000,000.00$ reais/year and the total operating time of $539400 \mathrm{~min} /$ year. If the machine was optimized, reducing its time by approximately $15 \%$, while the total time of the procedure would decrease around $8 \%$. The production would require $496240 \mathrm{~min} / \mathrm{year}$ and the cost would decrease to $\mathrm{R} \$ 1,800,000.00$ reais/year resulting in approximately $\mathrm{R} \$ 200,000.00$ saving in the year.

The purpose of the Lean Six Sigma methodology was optimization the machine and consequently the production flow. The aim is savings resources and improve the lead time in the process.

Through VMS and SIPOC (Lean) obtained the identification of the production flow and their interrelations in each transaction observing time and costs. This tool supports data analysis and identify the problem" machine. The offshoot of DMAIC (Six Sigma) and its statistical tools, adjust the machine to an ideal standard. In the DMAIC were described processes and reasoning, the focused is the machine, it was in trouble. Therefore, the start of the construction methodology begins at DMAIC, within D, the DEFINE.

In DEFINE, arose important information, which consists in comparing average of chrono time analysis of machines and chrono time analysis of which had low profitability. The results confirmed the problem analysis. This evaluation provided by SIPOC and VMS along the data showed the cause. During this period a team of experts formed the Belt.

The second phase consists of the MEASURE, two targets were set: one of trouble machine and another of process, respectively the first one, have a specific goal: reducing the time to 50 seconds to 43 seconds, optimizing the time of process in the machine in $15 \%$. The overall goal is to reduce the time from 98 to 91 seconds, in the role process, optimizing in $8 \%$. Also during this period, it was determined the overall indicator: profitability, to monitor and check the result.

The third phase, ANALYZE sought the removal of the variables that influence the machine. Through statistical tools such as Pareto chart and the Box plot was obtained the time dispersions, which could be observed by the belt.

Brainstorming raised possible causes for dispersion, which is causing the lowprofitability: 1. Over-on-metal, 2. Finishing and roughing time, 3. Advancement of the X-axis and 4. Dressing time. The mapping of SIPOC and of cause and effect diagram a have driven a discussion for a potential solution to the problem was priority: reducing machine time In the final case, the IMPROVE rated the Brainstorming and its assumptions. The analysis initials show options 1 and 2, however the first and second option is a problem of suppliers. As soon, machineroughing time was discussed as a good possible to correct the machine. The project to change the machine parameters as previously discussed in other phases. After the planned adjustment of the machine, there was a new stratification and new boxplot.

The result after the adjustment of the machine exceeded the targets. The target specifically achieved a $32 \%$ optimization, which reduced the time from 51 to 32 seconds operation. Consequently, the overall goal came to $15 \%$, reducing from 98 to 82 seconds. Therefore, the result increased the reduction in spending more than expected.

Finally, the $\mathrm{C}$ (CONTROL) verified quality in the process. The new machine parameters were satisfactory, this leading the maintenance to new parameters. In order not go back the problem, the document of the machine have an adjustment, as well as monthly reports to monitor machine performance and process. 


\section{Case number 2}

In Case 2, it was developed a reasoning map to optimize the cycle time of the inner ring with a goal of $8 \%$ in a cell 1 of a factory production unit. Using DEFINE, it was verified that the gain with the reduction is significant, because reaching the goal, the cycle time of the cell is reduced, reaching a saving of $\mathrm{R} \$ 161,820.00$ / year. The project is a priority for the cell, because in addition to generating an economy, the project will help achieve production targets by 25,000 parts /month and the current average is 23,000 parts / month. With MEASURE chronoanalysis was used to focus on the problem. It has been found that the average time of a NOVA machine is higher than the other processes of the inner ring cell becoming the bottleneck of the cell.

Is observed that the NOVA machine is the bottleneck of cell 1 , therefore reducing the cycle time of the NOVA machine by $15 \%$. The overall goal of $8 \%$ reduction in cell cycle time is reached. Using the ANALYZE it was possible to organize the process through the Pareto's chart and verify the dispersion of the times in each stage of the NOVA machine. Is observed that the longest times are located in Roughing, where the greatest dispersion occurs. A Brainstorming was elaborated where it was found that the items with the highest score are: Excess of OverMetal and Finishing and Roughing. With IMPROVE, according to the Brainstorming and stratifications carried out the project was directed to changes of the machine parameters and discarded the over - metal item momentarily due to its restrictions. In this way there was a prioritization of the solutions. The highest scoring items generated by Brainstorming will be treated as follows:

1) Will be discarded due to the difficulties of third party parts supply and design changes;

2) Proposal to change the machine parameters;

3) Proposal to change the machine parameters;

4) Proposal to change the machine parameters;

5) Due to being considered items of weak impact in the resolution of the problems, but can be used in cases of necessity.

However, with the reduced cycle time of the NOVA machine, there was a reduction to $32.35 \%$, exceeding the priority target of $15 \%$. With the application of CONTROL, the target cycle time of the cell was exceeded from $8 \%$ to $15.6 \%$. Through the controls with the new parameters: profile evaluation, roughness and circularity the goal was achieved.

\section{Case number 3}

In Case 3 the goal is to reduce the consumption of tools and machine optimization in the production line of an auto parts Supplier Company. As a starting point, tool costs ( $\mathrm{R} \$ 3.38$ per linear meter) were raised and a low performance of CBN grinding wheels and high machining times were observed. As it is a grinding wheel with a cost of approximately $\mathrm{R} \$ 2,300.00$ each, hence the importance of treating not only the reduction of tool consumption but also the reduction of machining times. The grinding wheels are used to machine various types of gear groups each with their respective costs per linear meter.

In the current situation, the average monthly cost of reworking this material is $\mathrm{R} \$$ $109,081.48$ / month, with an annual cost of $\mathrm{R} \$ 1,308,979.47$. The Ishikawa`s tool (6M) was also used, in order to identify the causes of the problem. The main causes were: 1) system "pushed" the supplier sends everything that has covered; 2) lack of programming for items with closed requisition; 3) high hardness of the parts and low service life of the covers. 
Afterwards, the Theoretical Analysis Model (MTA) was used with the 5Why tool and the Improvement Prioritization Matrix with the GUT technique to map the actions more clearly until reaching the reduction objective.

The MTA, with 5 Why, is an approach in the form of an array of questions guiding the group in getting answers to particular problems or action plans. It's a systematic to better understand a certain situation, exploring its different aspects. The priorities set out in 100\% and $70 \%$ relate to the priority level of each topic, established by the team of improvements and focusing on solving the problem established, and in the penultimate column the proposed solutions to the problems. Next, the prioritization matrix was performed, whose objective is to reduce and order, in a rational way, the number of items to be implanted and later ordered in the matrix. It is a matrix specially constructed to order a list of items, a tool for decision making, since it establishes a prioritization, which may or may not be based on criteria with defined weights. The weights were defined in conjunction with the factory floor (machine users) and Factory Improvement Project team.

Table 4 Matriz GUT

\begin{tabular}{|c|c|c|c|c|c|}
\hline & \multicolumn{5}{|c|}{ Improvement Priorization matrix } \\
\hline \multicolumn{6}{|c|}{ Project: Kapp machines optimization } \\
\hline & Topic & $\mathrm{U}$ & $\mathrm{T}$ & Priorization & MTA priorization \\
\hline & $\begin{array}{l}\text { Systematic implementation for teeth } \\
\text { grinding experience }\end{array}$ & 5 & 5 & 125 & \\
\hline & Monitoring after implementation & 5 & 5 & 125 & \\
\hline & $\begin{array}{l}\text { After experience / Implement } \\
\text { correction formulary }\end{array}$ & 5 & 5 & 125 & \\
\hline & $\begin{array}{l}\text { Life time controlling of grinding } \\
\text { wheels }\end{array}$ & 3 & 3 & 27 & \\
\hline & $\begin{array}{l}\text { Execute inventory checking via } \\
\text { SAP system define systematic for } \\
\text { demand calculation }\end{array}$ & 5 & 3 & 75 & \\
\hline & $\begin{array}{l}\text { Implement sensors against crashing } \\
\text { and train operators }\end{array}$ & 5 & 5 & 125 & \\
\hline & Surface coating development & 3 & 3 & 27 & \\
\hline & $\begin{array}{l}\text { Negotiate purchase price of tooling } \\
\text { due to the productivity gain for the } \\
\text { supplier }\end{array}$ & 3 & 3 & 27 & \\
\hline & New development cost reduction & 3 & 1 & 15 & \\
\hline & $\begin{array}{c}\text { Monitoring of cycle time after } \\
\text { improvements }\end{array}$ & 5 & 3 & 75 & \\
\hline & $\begin{array}{l}\text { Identify products with possibility to } \\
\text { share the same development }\end{array}$ & 5 & 5 & 125 & \\
\hline \multirow{4}{*}{ G } & The waste could be & \multicolumn{2}{|c|}{ Action should be taken } & & In case of not act \\
\hline & 5 high importance & \multicolumn{2}{|c|}{5 Imediately } & & 5 highly worst \\
\hline & $3+/-$ importance & \multicolumn{2}{|c|}{3 Can wait } & 1 & 3 stable \\
\hline & 1 low importance & \multicolumn{2}{|c|}{1 No priority } & & 1 improve \\
\hline
\end{tabular}

Source: Authors (2017) 
The Gut technique was used with the matrix. The procedure used to prepare the Matrix was to list all the problems (or risks) related to what was treated in the situation to be explored.

Then we assign a note ( 1 to 5) for each problem, in three aspects: Severity, Urgency and Trend (hence the name GUT). Gravity is the size of the impact of that problem in case it happens. Urgency is related to the time that this problem should take to happen, the greater the urgency the less time available to solve this problem. Trend is the potential of the problem, ie, "If I do not solve this problem now, will it get worse little by little or will it get worse?" Summing up the valuesof each of these aspects (Severity, Urgency and Trend), we have a priority. The problems with the highest priority are those that you must treat first, precisely because they are the ones with the highest Severity, Urgency and Tendency. The others you can leave for later or even ignore if necessary.

The major priorities in the matrix (125 points) are due to: the criticality of each item defined by the team responsible for the project, based on the importance represented for the resolution of the problems and so on in a degree of greater importance. So after several brainstorms, the matrix was completed. For each Kapp machine, they produce various groups of materials (gears, grinding wheels and planetary). In 2014, beginning of the project to reduce the consumption of tools and machining times, below figure 1 brings the monitoring of the situation of 2014. The cost of the month of January spent with tools was R $\$ 153,426.00$. The monthly cost per linear meter of the groupings was calculated ( $\mathrm{R} \$ 153,426.00$ / 53469 linear meter) at $\mathrm{R} \$ 2.83$ per linear meter.

\section{CONCLUSION}

The Lean and Six Sigma programs have emerged in different scenarios and epochs, and although they use different methodologies, both aim as the main result of a process to increase productivity and quality. In the case of the Lean, the initial strategy of conducting isolated kaizens in areas, sectors or processes generated specific results awoke the companies to the necessary organizational culture change that should accompany the introduction of these programs.

In the case of Six Sigma, the need for a staff structure capable of applying statistical tools (so-called Green Belts, Black Belts and Master Black Belts), with partial or full dedication to improvement projects, combined with relatively long generation time of expressive results, it ended up cooling the rhythm of the actions and, consequently, the achievement of the planned results.

Lean Six Sigma covers everything from operational and tactical aspects of quality to customer satisfaction. The contribution of this methodology is to reduce costs, times and activities in the pursuit of productivity, as well as being concerned with adding value to the process and bringing the customer a new perception of the product. Lean Six Sigma is the theory and practice of the four case studies. It can be seen that by means of the aforementioned techniques, in these cases there is a significant improvement in operating times, reliability / quality and a cost reduction without loss of capacity, in particular in these cases there was an increase in production capacity.

The Lean and Six Sigma philosophies worked simultaneously bring significant results. The integration of tools and methods of these two management practices show harmony and efficiency in process improvement. Therefore, strategically aligning holistic and timely views on the same focus presents progress in operational times, reduction of losses and costs involved directly and indirectly in production. The Lean Six Sigma methodology proved to be satisfactory and effective. 


\section{REFERENCES}

Habidin, N.F., Yusof, S.M. Relationship Between Lean Six Sigma, Environmental Management Systems, and Organizational Performance in the Malaysian Automotive Industry[J]. International Journal of Automotive Technology, 2012,(9):1119-25

Anthony J., Kumar M. Lean and Six Sigma Methodologies in NHS Scotland: An Empirical Study and Directions for Future Research[J]. Quality Innovation Prosperity/ Kvalita Inovácia Prosperita, 2012,(2):19-34

Stan, L., Marascu, K. V. Techniques to Reduce Costs Sustainable Quality in the Industrial Companies[R]. 8th International DAAAM Baltic Conference - Industrial Engineering\|, Tallinn, Estonia, 2012

Aghili, S. Throughput Metrics Meet Six Sigma[J]. Management Accounting Quarterly, $2011,(2): 12-17$

Okhovat, M.A., Ariffin, M.K.A.M., Nehzati, T., Hosseini, S.A. Development of World Class Manufacturing Framework by Using Six-Sigma, Total Productive Maintenance and Lean[J]. Scientific Research and Essays, 2012,(7):4230-4241

Hoon K, Anbari F. K. Benefits, Obstacles, and Future of Six Sigma[J]. Research Technovation, 2006,(26):708-715

Celis, L. M. O., Garcia S. M. J Modelo tecnológico para el desarrollo de proyectos logsíticos usando Lean Six Sigma[J]. Revistas Cientfíicas de América Latina y el Caribe, España y Portugal, 2012,(28):23-43

Chen T., Discussion on Integration of Lean Production and Six Sigma Management[J]. Internation Business Research, 2008,(1):38-42

Todorut, V. A., Rãbontu I. C. CRÎ NU D. Lean Management - The Way to a Performant Enterprise[J]. Annals of the University of Petroşani, Economics, 2012,10(3):333-340

Bhamu, J., Sangwan K. .S. Lean Manufacturing: Literature Review and Research Issues[J]. International Journal of Operations \& Production Management, 2014,34(7):876-940

Basu, R. Implementing Six Sigma and Lean: A Practical Guide to Tools and Techniques[M]. Butterworth-Heinemann, 2009

Palanisamy, V., Divyapriya, P. Six Sigma Approach for Effective Process Chain in a Manufacturing Industry[J]. Middle-East Journal of Scientific Research, 2013,17(12):1891-1895

Chakravorty, S.S. Six Sigma Programs: An Implementation Model[J]. International Journal of Production Economics, 2009,(1):1-16

Yin, Robert K. Case Study Research: Design and Methods[M]. Thousand Oaks, California, Sage Publications, 1994 